\title{
Isolation of quercetin and mandelic acid from Aesculus indica fruit and their biological activities
}

\author{
Muhammad Zahoor*, Sadaf Shafiq, Habib Ullah, Abdul Sadiq and Farhat Ullah
}

\begin{abstract}
Background: In this study Aesculus indica fruit was subjected to isolation of phytochemicals. Two antioxidants quercetin and Mandelic acid were isolated in pure state. The free radical scavenging and acetyl choline esterase inhibitory potential of the crude extract and sub fractions were also determined.

Results: The antioxidant capacity of crude extract, fractions and isolated compounds were determined by DPPH and ABTS methods. Folin-Ciocalteu reagent method was used to estimate the total phenolic contents and were found to be $78.34 \pm 0.96,44.16 \pm 1.05,65.45 \pm 1.29,37.85 \pm 1.44$ and $50.23 \pm 2.431$ (mg/g of gallic acid) in crude extract, ethyl acetate, chloroform, n-hexane and aqueous fractions respectively. The flavonoid concentration in crude extract, ethyl acetate, chloroform, n-hexane and aqueous fraction were; $85.30 \pm 1.20,53.80 \pm 1.07,77.50 \pm 1.12$, $26.30 \pm 1.35$ and $37.78 \pm 1.25$ (mg/g of quercetin) respectively. The chloroform fraction was more potent against enzymes, acetyl choline esterase and butyryl choline esterase $\left(I C_{50}=85\right.$ and $160 \mu \mathrm{g} / \mathrm{ml}$ respectively). The phenolic compounds in the crude extract and fractions were determined using HPLC standard method. Chlorogenic acid, quercetin, phloroglucinol, rutin, mandelic acid and hydroxy benzoic acid were detected at retention times 6.005, $10.062,22.623,30.597,35.490$ and 36.211 in crude extract and different fractions. The ethyl acetate fraction was rich in the targeted compounds and was therefore subjected to column isolation. The HPLC chromatogram of isolated compounds showed single peak at specified retention times which confirms their isolation in pure state. The isolated compounds were then characterized by FTIR and NMR spectrophotometric techniques.

Conclusion: The Aesculus indica fruit extracts showed antioxidant and anticholine esterase inhibitory potentials. Two bioactive compounds were isolated in the pure form ethyl acetate fraction. From results it was concluded that the fruit of this plant could be used to minimize oxidative stress caused by reactive oxygen species.
\end{abstract}

Keywords: Aesculus indica, HPLC, Quercetin, Mandelic acid

\section{Background}

Plants have been remained the main source of medication for humans since time immorial due to their easy availability and low cost. The humans also uses medicinal plants to treat various diseases in animals as well $[1,2]$. According to a survey conducted by W.H.O (World Health Organization) about $80 \%$ of world population uses herbal medication [3]. The use of medicinal plants for the treatment of various diseases in more prevalent in the developing countries About 50,000 out

\footnotetext{
* Correspondence: mohammadzahoorus@yahoo.com Department of Chemistry, University of Malakand, Chakdara, Dir Lower KPK, Pakistan
}

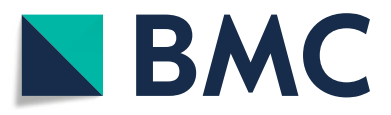

(๑) The Author(s). 2018 Open Access This article is distributed under the terms of the Creative Commons Attribution 4.0 International License (http://creativecommons.org/licenses/by/4.0/), which permits unrestricted use, distribution, and

reproduction in any medium, provided you give appropriate credit to the original author(s) and the source, provide a link to the Creative Commons license, and indicate if changes were made. The Creative Commons Public Domain Dedication waiver (http://creativecommons.org/publicdomain/zero/1.0/) applies to the data made available in this article, unless otherwise stated. of 422,000 flowering plants have been documented to have potential pharmacological effects [4]. Initially these plants were used in crude form as drugs (powders, tinctures, in form of tea etc.) by humans [5]. The successful isolation of primary drugs like quinine, cocaine and codeine from plants opened a new era of herbal medication. Further work in this field led to the isolation of morphine from opium in the early 19th century, which was a milestone in herbal medication [6,7].

The oxygen we take in respiration is converted into water. However sometime it is partially oxidized into a number of products collectively known as reactive oxygen species which are free radicals and they harm cells and biologically important substances like DNA 
and proteins resulting in a number of complication like aging, cancer etc. A substance which inhibits oxidation is known as anti-oxidant. The present interest in the analysis and use of antioxidant from medicinal plants is due to its wide use in scientific research and in industries [5-9]. Antioxidants maintain health and serve to decrease the levels of free radicals [9]. Many synthetic antioxidants are added to food as preservative in food industries. Some of them have shown toxic properties and are carcinogens. Therefore the scientists are forced to discover new antioxidants of nontoxic nature. Amongst the many sources plant are considered the most suitable and nontoxic [10].

Aesculus indica is member of Sapindaceae family. It is herbaceous plant which is commonly known as Jawaz [11] and found in temperate regions of Asia (Nepal, India, Pakistan and Afghanistan) at an altitude ranging from 900 to $3600 \mathrm{~m}$ [12]. Jawaz trees can attain an average height of $22.5 \mathrm{~m}$. They shed leaves in winter. In the months of May and June these trees are in full bloom and yield multi colored buds. These buds on fertilization yield huge amount of seeds, which in the hilly area like Kashmir are consumed Kashmir stag [13].

Aesculus indica has remarkable medicinal properties. For the treatment of diabetes the whole plant is beneficial. Its fruit is also used in colic disorder. It is highly effective in complaints associated with veins for instance phlebitis, hemorrhoids, varicose veins and in ulcers to prevent thrombosis. Moreover also it also helps in fighting against some types of migraine and effusions of blood. Further it helps in limb complaints and frost bite. Its seed are also used as astringent and nutritious. The oil obtained from its seeds is used as cure for many skin diseases and also gives relief in rheumatism. Hitherto researchers have successfully isolated about 210 chemical compounds from Aesculus. Compounds like triterpenoid, triterpenoid glycosides (saponins), flavonoids, coumarins, carotenoid, long fatty chain compounds are only a few to name amongst them. In literature it is reported that Aesculus indica contain a mixture of saponins. One of these saponins is known as Aescine which has the ability of crystal formation. The aesculine obtained from this plant is used medicinally. The hydroxycoumarin glycoside aesculine reported from this plant, absorbs ultra violet rays at the bark of the branch [11-15].

From the last two decades the seeds and fruits of Aesculus have remained as major target for chemical investigators to isolate compounds from it [14]. Owing to the importance of natural antioxidants and Aesculus indica, this study was aimed to evaluate Aesculus indica for phenolic and flavonoid contents. The antioxidant and acetyl choline esterase inhibitory potential were also determined. Two natural antioxidants, quercetin and Mandelic acid were isolated from this plant and characterized through HPLC, FTIR and NMR.

\section{Results and discussion}

The present investigation has led to the isolation of two reported compounds that have been isolated for the first time from Aesculus indica fruit. The structures and identification of isolated compounds were carried out with the help of different techniques FT-IR, ${ }^{1} \mathrm{H}$-NMR and HPLC. The biological activities of the isolated compounds and different fractions of crude extracts of the Aesculus indica fruit were also determined.

\section{DPPH radical scavenging effect}

The antioxidant potential of crude extract and sub-fractions (ethyl acetate n-hexane, chloroform and aqueous fractions) were studied using DPPH and ABTS assays (concentration ranging from 1000, 500, 250, 125 and $62.5 \mu \mathrm{g} / \mathrm{ml}$ ). The DPPH antioxidant assay is based on the ability of an antioxidant to scavenge DPPH free radical. The antioxidant donate electrons to DPPH free radical which results in color changes from purple to yellow. The percent free radical scavenging potential were found to be higher for chloroform fraction with $\mathrm{IC}_{50}$ value of $50 \mu \mathrm{g} / \mathrm{ml}$ followed by crude extract $\left(\mathrm{IC}_{50}=\right.$ $60 \mu \mathrm{g} / \mathrm{ml}$ ) (Table 1 and Additional file 1: Figure S1). The $\mathrm{IC}_{50}$ values of ethyl acetate; aqueous and $\mathrm{n}$-hexane fractions were; 155,250 and $725 \mu \mathrm{g} / \mathrm{ml}$ respectively. Ascorbic acid was used as positive control and its $\mathrm{IC}_{50}$ value was $15 \mu \mathrm{g} / \mathrm{ml}$.

\section{ABTS radical scavenging effect}

Chloroform fraction of Aesculus indica showed highest activity against ABTS free radical at various concentrations ranging from 1000, 500, 250, 125 and $62.5 \mu \mathrm{g} / \mathrm{ml}$ $\left(\mathrm{IC}_{50}=65 \mu \mathrm{g} / \mathrm{ml}\right)$. The ABTS free radical scavenging potential of chloroform fraction was comparable to that of DPPH free radical scavenging capacity (Table 1 and Additional file 1: Figure S2). The crude extract also showed good antioxidant activity with $\mathrm{IC}_{50}=105 \mu \mathrm{g} / \mathrm{ml}$, followed by ethyl acetate, chloroform, aqueous and $n$ hexane fractions with $1 C_{50}$ of 183,350 , and $760 \mu \mathrm{g} / \mathrm{ml}$ respectively. The ABTS percent inhibitions were compared with the positive control ascorbic acid with $\mathrm{IC}_{50}$ value of $23 \mu \mathrm{g} / \mathrm{ml}$.

\section{Acetyl cholinesterase inhibition assays}

The hydrolysis of acetylcholine can be stopped if AChE in the brain is inhibited. A number of plants have been used traditionally to enhance and alleviate other cognitive function and symptoms associated with Alzheimer's disease. The AChE percent inhibition and their $1 C_{50}$ values against the crude extract of Aesculus indica and their sub fraction are given Table 2 . The crude extract 
Table 1 Percent DPPH and ABTS radical scavenging potential of crude extract and their sub fractions of Aesculus indica fruit using ascorbic acid as standard

\begin{tabular}{|c|c|c|c|c|c|}
\hline Samples & $\begin{array}{l}\text { Concentrations } \\
(\mu \mathrm{g} / \mathrm{mL})\end{array}$ & $\begin{array}{l}\text { ABTS percent inhibition } \\
(\text { mean } \pm \text { S.E.M) }\end{array}$ & $\begin{array}{l}\text { ABTS IC } \\
(\mu \mathrm{g} / \mathrm{mL})\end{array}$ & $\begin{array}{l}\text { DPPH percent inhibition } \\
(\text { mean } \pm \text { S.E.M })\end{array}$ & DPPH IC $C_{50}(\mu \mathrm{g} / \mathrm{mL})$ \\
\hline \multirow[t]{5}{*}{ Crude } & 1000 & $85.58 \pm 1.31 \mathrm{~ns}$ & & $90.28 \pm 0.50 \mathrm{~ns}$ & \\
\hline & 500 & $72.26 \pm 1.18^{* * *}$ & & $79.21 \pm 0.48^{* * *}$ & \\
\hline & 250 & $68.59 \pm 1.00^{* * *}$ & 105 & $70.01 \pm 0.80^{* * *}$ & 60 \\
\hline & 125 & $54.93 \pm 1.49^{* * *}$ & & $58.23 \pm 1.13^{* * *}$ & \\
\hline & 62.5 & $42.66 \pm 2.25^{* * *}$ & & $50.45 \pm 0.52^{* * *}$ & \\
\hline \multirow[t]{5}{*}{ Chloroform } & 1000 & $83.39 \pm 0.46^{*}$ & & $84.27 \pm 0.54^{* * *}$ & \\
\hline & 500 & $72.58 \pm 0.54^{* * *}$ & & $73.66 \pm 1.79^{* * *}$ & \\
\hline & 250 & $63.30 \pm 0.67^{* * *}$ & 65 & $64.56 \pm 2.23^{* * *}$ & 50 \\
\hline & 125 & $56.25 . \pm 2.14^{* * *}$ & & $59.24 \pm 0.69^{* * *}$ & \\
\hline & 62.5 & $51.83 \pm 0.84^{* * *}$ & & $47.36 \pm 0.76^{* * *}$ & \\
\hline \multirow[t]{5}{*}{ Ethyl acetate } & 1000 & $78.31 \pm 0.53^{* * *}$ & & $79.04 \pm 0.72^{* * *}$ & \\
\hline & 500 & $66.99 \pm 0.79^{* * *}$ & 183 & $68.77 \pm 1.61^{* * *}$ & \\
\hline & 250 & $56.29 \pm 0.75^{* * *}$ & & $57.33 \pm 0.91^{* * *}$ & 155 \\
\hline & 125 & $44.93 \pm 0.88^{* * *}$ & & $46.70 \pm 1.22^{* * *}$ & \\
\hline & 62.5 & $39.49 \pm 0.63^{* * *}$ & & $40.73 \pm 0.37^{* * *}$ & \\
\hline \multirow[t]{5}{*}{ Aqueous } & 1000 & $70.50 \pm 0.74^{* * *}$ & & $73.82 \pm 1.20^{* * *}$ & \\
\hline & 500 & $60.10 \pm 2.29^{* * *}$ & 325 & $62.62 \pm 1.16^{* * *}$ & \\
\hline & 250 & $44.84 \pm 2.67^{* * *}$ & & $49.47 . \pm 0.58^{* * *}$ & 250 \\
\hline & 125 & $35.76 \pm 0.52^{* * *}$ & & $36.56 \pm 1.25^{* * *}$ & \\
\hline & 62.5 & $20.66 \pm 3.08^{* * *}$ & & $26.16 \pm 2.36^{* * *}$ & \\
\hline \multirow[t]{5}{*}{ n-hexane } & 1000 & $58.13 \pm 0.49^{* * *}$ & & $57.03 \pm 2.00^{* * *}$ & \\
\hline & 500 & $43.17 \pm 0.66^{* * *}$ & & $44.44 \pm 2.00^{* * *}$ & \\
\hline & 250 & $31.01 \pm 2.34^{* * *}$ & 760 & $35.22 \pm 1.06^{* * *}$ & 725 \\
\hline & 125 & $22.02 \pm 1.11^{* * *}$ & & $24.29 \pm 0.54^{* * *}$ & \\
\hline & 62.5 & $14.19 \pm 0.55^{* * *}$ & & $15.19 \pm 0.50^{* * *}$ & \\
\hline \multirow[t]{5}{*}{ Ascorbic acid } & 1000 & $89.94 \pm 0.86$ & & $94.35 \pm 0.7$ & \\
\hline & 500 & $86.29 \pm 0.79$ & & $87.90 \pm 0.96$ & \\
\hline & 250 & $77.32 \pm 2.23$ & 23 & $81.78 \pm 2.16$ & 15 \\
\hline & 125 & $69.97 \pm 3.26$ & & $73.61 \pm 0.85$ & \\
\hline & 62.5 & $61.28 \pm 1.31$ & & $63.31 \pm 0.76$ & \\
\hline
\end{tabular}

Ascorbic acid was used as a positive control. Data is represented as mean \pm S.E.M; $(n=3)$. Values significantly different as compared to positive control, ${ }^{*} P<0.05$; ${ }^{* * *} P<0.001, \mathrm{~ns}: P>0.05$

showed good percent inhibition with $\mathrm{IC}_{50}$ value of $145 \mu \mathrm{g} / \mathrm{ml}$. Amongst the sub fractions the chloroform fraction showed excellent percent inhibition with $\mathrm{IC}_{50}=$ $85 \mu \mathrm{g} / \mathrm{ml}$ followed by ethyl acetate, aqueous and n-hexane fraction with the $\mathrm{IC}_{50}$ of 190,350 and $760 \mu \mathrm{g} /$ $\mathrm{ml}$ respectively (Additional file 1: Figure S3). Galanthamine was used as a positive control in this study.

\section{Butyryl cholinesterase inhibition assay}

The inhibition potentials of the crude extract and their sub fraction of Aesculus indica against $\mathrm{BChE}$ are shown in the Table 2 and graphically in Additional file 1: Figure S4. The crude extract showed highest potential against $\mathrm{BChE}$ with $\mathrm{IC}_{50}$ value of $200 \mu \mathrm{g} / \mathrm{ml}$. Amongst the fractions the chloroform fraction showed promising percent inhibition with $\mathrm{IC}_{50}$ value of $160 \mu \mathrm{g} / \mathrm{ml}$. The other fractions like ethyl acetate, aqueous and n-hexane showed moderate percent inhibition with $\mathrm{IC}_{50}$ value of 210,400 and $870 \mu \mathrm{g} / \mathrm{ml}$ respectively. The AChE and BChE inhibition potential of Aesculus indica has not been studied by any researcher and is therefore innovative. 
Table 2 Percent AChE and BChE inhibition potentials of Aesculus indica fruit Crude extract and their sub fractions

\begin{tabular}{|c|c|c|c|c|c|}
\hline Sample & Concentration $(\mu \mathrm{g} / \mathrm{ml})$ & Percent AChE (mean \pm SEM) & AChE $I C_{50}(\mu \mathrm{g} / \mathrm{ml})$ & Percent BChE (mean \pm SEM) & $B C h E I C_{50}(\mu \mathrm{g} / \mathrm{ml})$ \\
\hline \multirow[t]{4}{*}{ Crude } & 1000 & $84.32 \pm 1.22^{* * *}$ & & $80.42 \pm 0.62^{* * * *}$ & \\
\hline & 500 & $71.23 \pm 1.40^{* * *}$ & 145 & $68.48 \pm 3.13^{* * *}$ & 200 \\
\hline & 250 & $58.07 \pm 1.20^{* * *}$ & & $52.54 \pm 1.26^{* * *}$ & \\
\hline & 125 & $49.37 \pm 0.02^{* * *}$ & & $45.70 \pm 0.52^{* * *}$ & \\
\hline \multirow[t]{4}{*}{ Chloroform } & 1000 & $86.21 \pm 0.49^{* * *}$ & & $82.56 \pm 0.70^{* * *}$ & \\
\hline & 500 & $74.24 \pm 0.81^{* * *}$ & 85 & $70.62 \pm 0.80^{* * *}$ & 160 \\
\hline & 250 & $64.22 \pm 0.67^{* * *}$ & & $58.011 \pm 2.68^{* * *}$ & \\
\hline & 125 & $53.82 \pm 0.41^{* * *}$ & & $48.05 \pm 0.99^{* * *}$ & \\
\hline \multirow[t]{4}{*}{ Ethyl acetate } & 1000 & $75.23 \pm 0.55^{* * *}$ & 190 & $69.12 \pm 2.60^{* * *}$ & 210 \\
\hline & 500 & $63.91 \pm 0.84^{* * *}$ & & $60.63 \pm 1.77^{* * *}$ & \\
\hline & 250 & $54.53 \pm 0.81^{* * *}$ & & $51.06 \pm 0.37^{* *}$ & \\
\hline & 125 & $40.61 \pm 2.30^{* * *}$ & & $37.80 \pm 0.60^{* * *}$ & \\
\hline \multirow[t]{4}{*}{ Aqueous } & 1000 & $71.46 \pm 0.71^{* * *}$ & & $68.87 \pm 1.90^{* * *}$ & \\
\hline & 500 & $58.10 \pm 1.36^{* * *}$ & 350 & $54.18 \pm 2.80^{* * *}$ & 400 \\
\hline & 250 & $45.14 \pm 0.67^{* * *}$ & & $38.60 \pm 3.46^{* * *}$ & \\
\hline & 125 & $32.71 \pm 0.76^{* * *}$ & & $26.11 \pm 0.42^{* * *}$ & \\
\hline \multirow[t]{4}{*}{ n-Hexane } & 1000 & $54.15 \pm 0.52^{* * *}$ & & $52.76 \pm 1.64^{* * *}$ & \\
\hline & 500 & $44.28 \pm 2.21^{* * *}$ & 760 & $40.56 \pm 0.88^{* * *}$ & 870 \\
\hline & 250 & $34.04 \pm 0.91^{* * *}$ & & $28.49 \pm 2.24^{* * *}$ & \\
\hline & 125 & $25.23 \pm 0.88^{* * *}$ & & $21.39 \pm 0.69^{* * *}$ & \\
\hline \multirow[t]{4}{*}{ Galanthamine } & 1000 & $95.32 \pm 0.88$ & & $92.50 \pm 0.71$ & \\
\hline & 500 & $84.31 \pm 0.55$ & 48 & $80.66 \pm 1.20$ & 66 \\
\hline & 250 & $72.31 \pm 0.60$ & & $72.72 \pm 0.72$ & \\
\hline & 125 & $64.38 \pm 0.54$ & & $60.83 \pm 0.69$ & \\
\hline
\end{tabular}

Galanthamine was used as a positive control. Data is represented as (mean \pm S.E.M) $n=3$. Values significantly different as compared to positive control, ${ }^{* *} P<0.01$; ${ }_{* * *} P<0.001$

\section{Flavonoids and phenolic contents}

The crude extract showed highest phenolic content (78.34 $\pm 0.96 \mathrm{mg}$ GAE/g) followed by chloroform fraction $(65.45 \pm 1.29 \mathrm{mg} \mathrm{GAE} / \mathrm{g})$. The aqueous fraction ranked third with value of $50.23 \pm 2.431 \mathrm{mg}$ GAE/g while in ethyl acetate and n-hexane fractions moderate quantities were present $(44.16 \pm 1.05$ and $37.85 \pm 1.44 \mathrm{mg}$ GAE/g of dry sample respectively). The results are shown graphically in Additional file 1: Figure S5 while in tabulated form in Table 3.

The crude extract was rich in flavonoid content (85.30 $\pm 1.20 \mathrm{mg} \mathrm{QE} / \mathrm{g}$ of dry sample). Amongst the fractions the chloroform fraction was rich in flavonoid content (77.50 $\pm 1.12 \mathrm{mg} \mathrm{QE} / \mathrm{g}$ of dry sample), followed by ethyl acetate $(53.80 \pm 1.07 \mathrm{mg} \mathrm{QE} / \mathrm{g}$ of dry sample), aqueous $(37.78 \pm 1.25 \mathrm{mg} \mathrm{QE} / \mathrm{g}$ of dry sample) and $\mathrm{n}$-hexane $(26.30 \pm 1.35 \mathrm{mg} \mathrm{QE} / \mathrm{g}$ of dry sample) respectively (Table 3 and Additional file 1: Figure S6).

\section{Linear correlation of total phenolic and flavonoid contents vs antioxidant and anticholinesterase activities} A linear correlation of total phenolic and flavonoid content vs various biological activities such as antioxidant (DPPH, ABTS) and Anticholinesterase (AChE, BChE)

Table 3 Total phenolic and total flavonoid contents in Aesculus indica fruit's crude extract and Their sub fractions

\begin{tabular}{lll}
\hline Samples & Total phenolic (mg GAE/g) of dry sample) & Total Flavonoid (mg QE/g of dry sample) \\
\hline Crude & $78.34 \pm 0.96$ & $85.30 \pm 1.20$ \\
Chloroform & $65.45 \pm 1.29$ & $77.50 \pm 1.12$ \\
Ethyl acetate & $44.16 \pm 1.05$ & $53.80 \pm 1.07$ \\
n-hexane & $37.85 \pm 1.44$ & $26.30 \pm 1.35$ \\
aqueous & $50.23 \pm 2.431$ & $37.78 \pm 1.25$ \\
\hline
\end{tabular}


have been shown in the Fig. 1. The regression value of $\% \mathrm{AChE}$ inhibition vs total phenolic content (Fig. 1c) and \% BChE (Fig. 1d) are 0.669 and 0.764 respectively. Similarly \% DPPH scavenging vs TPC (Fig. 1a) and \% ABTS (Fig. 1b) are 0.745 and 0.665 respectively. The regression value of \% AChE VS TFC (Fig. 1g) and \% BChE (Fig. 1h) are 0.859 and 0.861 respectively. Also the $\% \mathrm{DPPH}$ value vs TFC (Fig. 1e) and \% ABTS (Fig. 1f) are 0.871 and 0.901 respectively. The good correlations have been observed between total flavonoid versus \% DPPH and \% ABTS. While moderate correlations have been established between \% ABTS and \% AChE vs total phenolic. From the regression values it was concluded that the antioxidant capacities exhibited by the extracts were due to the presence of high phenolic and flavonoid contents.

\section{Identification of phenolic compounds in Aesculus indica fruit through HPLC analysis}

The bioactive compounds present in the crude extract and fractions were identified by comparing their chromatograms with that of standards chromatogram (Fig. 2). In the crude extract only four phenolic compounds quercetin, phloroglucinol, mandelic acid and hydroxy benzoic acid were identified (Fig. 3). Among the four phenolic compounds quercetin was present in greater concentration followed by hydroxy benzoic acid,

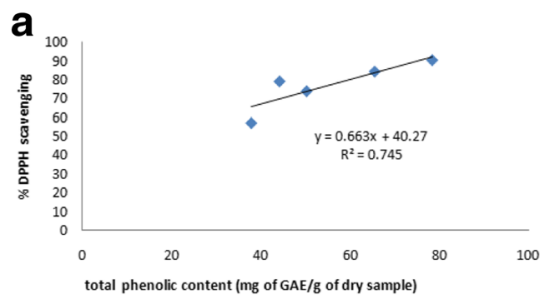

Correlation of total phenolic content vs $\%$ DPPH scavenging

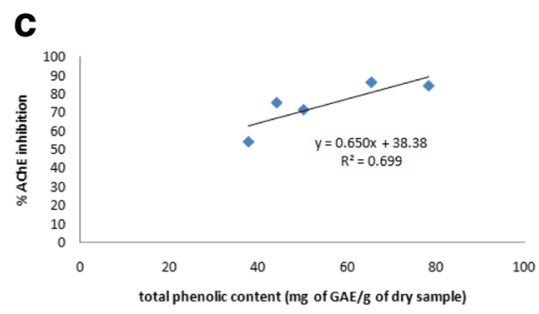

Correlation of total phenolic content vs \% AChE inhibition

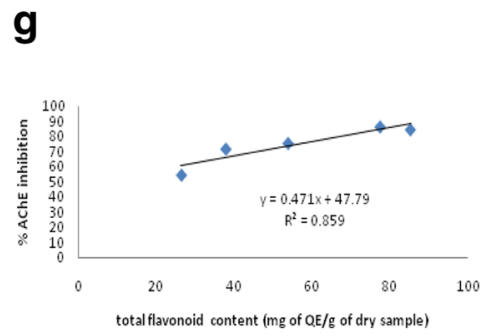

f

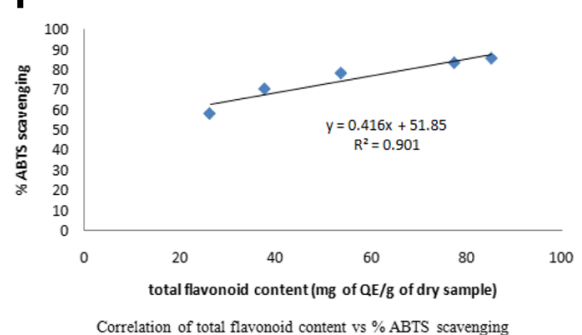

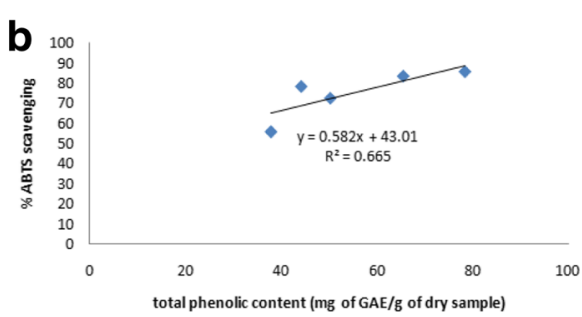

Correlation of total phenolic content $\mathrm{vs} \% \mathrm{ABTS}$ scavenging

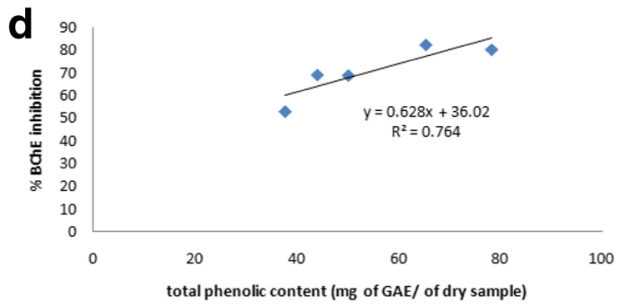

Correlation of total phenolic content vs $\% \mathrm{BChE}$ inhibition

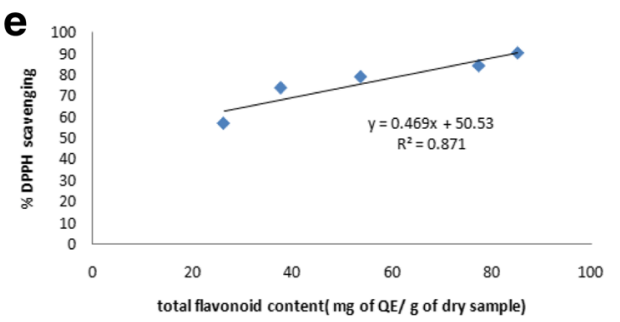

Correlation of total flavonoid content vs $\%$ DPPH scavenging

h

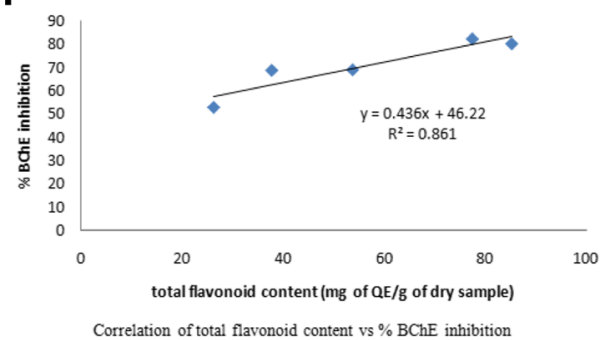

Fig. 1 Linear correlations for total Phenolics Vs AChE (c), BChE (d), DPPH (a), and ABTS (b) and for total Flavonoid content Vs AChE (g), BChE (h), $\operatorname{DPPH}(\mathbf{e})$, and ABTS (f) activities 


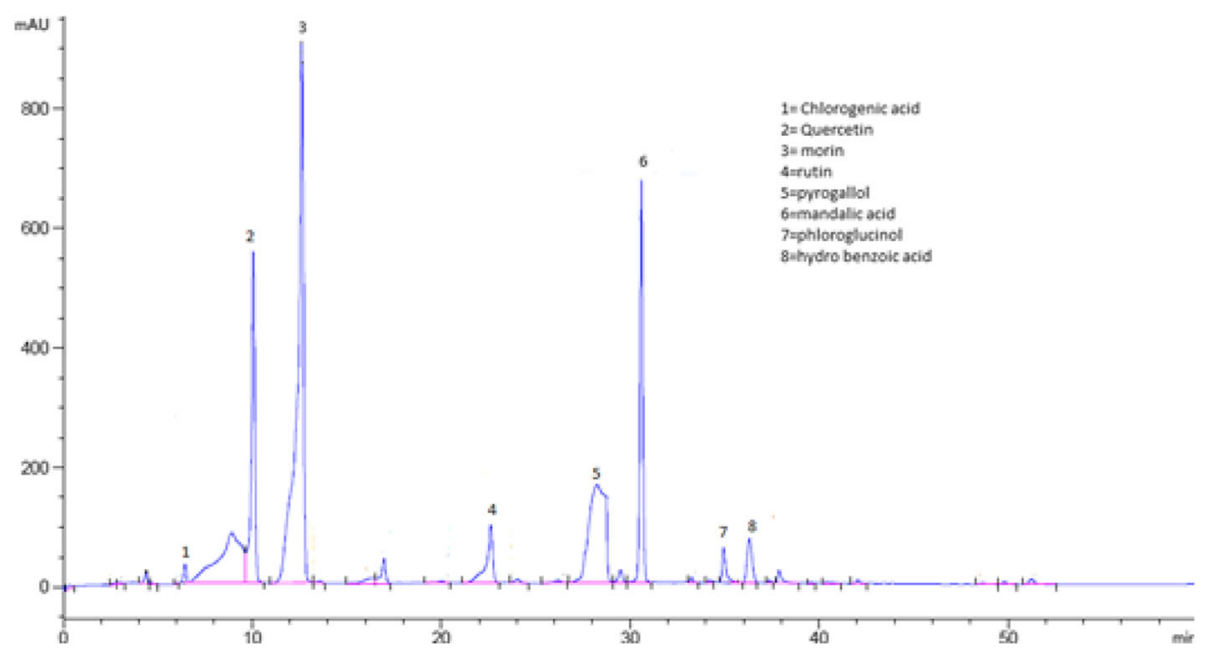

Fig. 2 HPLC chromatogram of standards

mandelic acid and phloroglucinol (Table 4). In ethyl acetate fraction only three phenolic compounds were detected i-e quercetin, mandelic acid and hydroxy benzoic acid (Fig. 4). Quercetin is present in greater concentration followed by hydroxy benzoic acid and mandelic acid (Table 5). In chloroform fraction only two phenolic compounds were detected $\mathrm{i}$-e chlorogenic acid and rutin (Fig. 5). Chlorogenic acid is present in greater concentration (Table 6). In n-hexane fraction only one phenolic compound was detected, and that was quercetin (Fig. 6) whose concentration was very low (Table 7). In Aqueous fraction five phenolic compounds were detected viz. chlorogenic acid, quercetin, rutin, mandelic acid and hydroxy benzoic acid (Fig. 7). Hydroxy benzoic acid was present in greater amount while other phenolic compounds were present in less amount (Table 8).

\section{Isolation of phenolic compounds from Aesculus indica} The ethyl acetate fraction was evaporated and its slurry with silica gel was developed which was then subjected to column chromatography. The column was eluted successively, using n-hexane and ethyl acetate gradient that afforded various sub fractions with increasing order of polarities (1 to 60\%). From the TLC analysis, fractions were combined according to their separation profile. Twelve sub fractions (C-1 to $\mathrm{C}$-12) were obtained which were then subjected to pencil silica gel column for further purification. The purified isolated compounds were then subjected to HPLC analysis for purity check and NMR and FTIR for structural elucidation. The single peak in HPLC chromatogram (broad peak) confirms their purity and isolation.

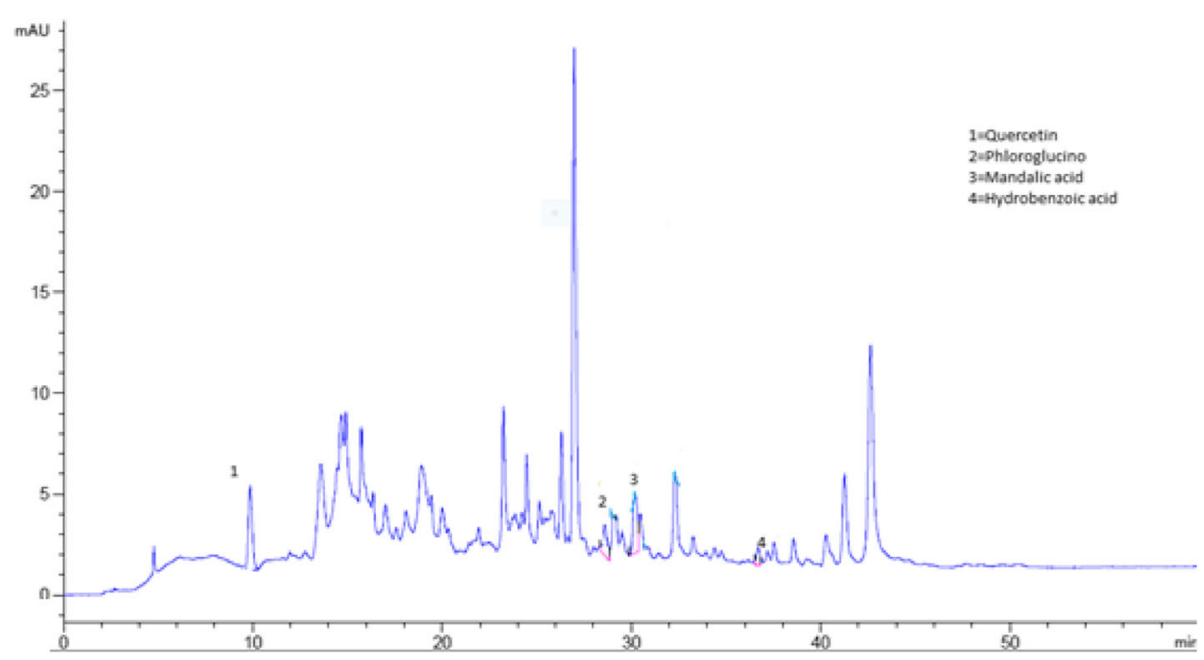

Fig. 3 HPLC Chromatogram of crude extract 
Table 4 Concentration of antioxidants in crude extract

\begin{tabular}{llllll}
\hline S. No & Peak & Retention time $(\mathrm{min})$ & Possible identity & Quantity $(\mathrm{mg} / 100 \mathrm{~g})$ & Identification Reference \\
\hline 1 & 2 & 10.062 & Quercetin & 1.22 & Standard \\
2 & 6 & 30.597 & Mandelic acid & 4.52 & Standard \\
3 & 7 & 35.490 & Phloroglucinol & 1.53 & Standard \\
4 & 8 & 36.211 & Hydroxy benzoic acid & 0.24 & Standard \\
\hline
\end{tabular}

\section{Compound 2 (Quercetin)}

The Quercetin; 2-(3,4-dihydroxy phenyl)-3,5,7-trihydroxy-4H-Chromen-4-one was isolated from the ethyl acetate fraction as yellow powder. Its molecular formula is $\mathrm{C}_{15} \mathrm{H}_{10} \mathrm{O}_{7}$ while its structural formula is given in Fig. 8 . The HPLC analysis was carried out to confirm their purity and isolation (Fig. 8). The FTIR spectra of isolated quercetin is shown in Additional file 1: Figure S7. The absorption bands at $3520 \mathrm{~cm}^{-1}$ representing hydroxyl group. The peak at $3050 \mathrm{~cm}^{-1}$ is for $\mathrm{C}-\mathrm{H}$ bond. The presence of aromatic nucleus is evident from aromatic $\mathrm{C}=\mathrm{C}$ bond stretching at1600 $\mathrm{cm}^{-1}$. In ${ }^{1} \mathrm{H}-\mathrm{NMR}$ (Additional file 1: Figure S8) spectral data $\left(\mathrm{CD}_{3} \mathrm{OD}\right)$ (Varian 300Mhz) the peaks at $6.28(1 \mathrm{H}, \mathrm{CH}), 6.48$ $(1 \mathrm{H}, \mathrm{CH}), 6.98(1 \mathrm{H}, \mathrm{CH}), 7.63(1 \mathrm{H}, \mathrm{CH})$ and $7.82(1 \mathrm{H}, \mathrm{CH})$ ppm show the aromatic proton at C-6, C-8, C-5, C-6 and $\mathrm{C}-2$ respectively. The present data was in good correlation to the previously reported data by Selvaraj et al. [16].

\section{Compound 6 (Mandelic acid)}

The compound 6 mandelic acid (2-hydroxy-2-phenyle acetic acid) was isolated from the ethyl acetate fraction as white crystalline solid. Its molecular formula is $\mathrm{C}_{8} \mathrm{H}_{8} \mathrm{O}_{3}$ and its structural formula is shown in Fig. 8. The HPLC chromatogram was developed to confirm their purity and isolation (Fig. 8). The single broad peak in HPLC chromatogram confirms its isolation in the pure form. The FTIR spectra of isolated mandelic acid is shown in Additional file 1: Figure S9. The absorption broad band at $3400 \mathrm{~cm}^{-1}$ indicating the presence of carboxyl group. The peak at $3050 \mathrm{~cm}^{-1}$ representing $\mathrm{C}-\mathrm{H}$ group while aromatic $\mathrm{C}=\mathrm{C}$ bond stretching at $1600 \mathrm{~cm}^{-1}$ shows the presence of the aromatic nucleus and the peak at $1710 \mathrm{~cm}^{-1}$ shows the carbonyl functionality. The ${ }^{1} \mathrm{H}$-NMR spectra (Additional file 1: Figure S10) shows a singlet peak at $12.4 \mathrm{ppm}$ indicating carboxylic proton and the signal at $5.2 \mathrm{ppm}$ can be assigned to aliphatic proton at $\mathrm{C}-1$ and $\mathrm{C}-2$ respectively. The doublets signal at 7.6, 7.4 $\mathrm{ppm}$ indicating the aromatic proton at C-4 and C-5 respectively. In the same way the triplet signal appeared at $7.1 \mathrm{ppm}$ which could be assigned to aromatic proton at C-6.

\section{Antioxidant potential of the isolated compounds}

The phenolic compounds; quercetin and mandelic acid isolated from the fruit of Aesculus indica showed excellent antioxidant activity against DPPH and ABTS free radicals at different concentration ranging from 62.5$1000 \mu \mathrm{g} / \mathrm{ml}$. The percent free radical scavenging potential was higher for quercetin with $\mathrm{IC}_{50}$ value of $78 \mu \mathrm{g} / \mathrm{ml}$ as compared to mandelic acid $\left(\mathrm{IC}_{50}=118 \mu \mathrm{g} / \mathrm{ml}\right)$. The quercetin and mandelic acid also exhibited good antioxidant activity against free radical ABTS with $\mathrm{IC}_{50}$ values of 180 and $242 \mu \mathrm{g} / \mathrm{ml}$ respectively (Table 9 and

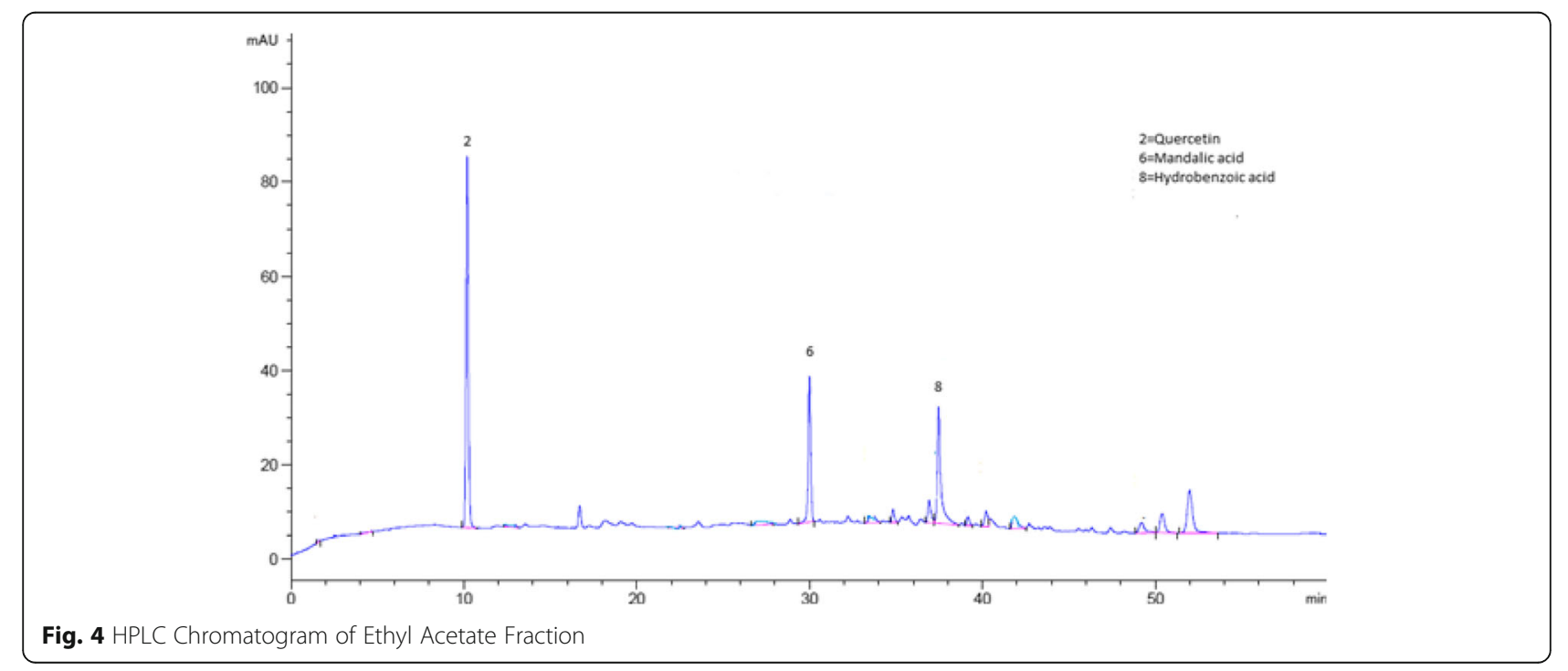


Table 5 Concentration of antioxidants in ethyl acetate fraction

\begin{tabular}{llllll}
\hline S. No & Peak & Retention time $(\mathrm{min})$ & Possible identity & Quantity $(\mathrm{mg} / 100 \mathrm{~g})$ & Identification reference \\
\hline 1 & 2 & 10.062 & Quercetin & 6.74 & Standard \\
2 & 6 & 30.597 & Mandelic acid & 5.42 & Standard \\
3 & 8 & 35.490 & Hydroxy benzoic acid & 0.965 & Standard \\
\hline
\end{tabular}

Additional file 1: Figures S11 and S12). Ascorbic acid was used as a standard and its $\mathrm{IC}_{50}$ value was $38,58 \mu \mathrm{g} /$ $\mathrm{ml}$ for DPPH and ABTS respectively.

\section{Conclusion}

In this study fruit of Aesculus indica was screened for phenolic compounds. The antioxidant potential of the crude extract, fractions and isolated compounds were determined through DPPH and ABTS assays. The crude extract and different fraction were also tested for their acetyl choline esterase inhibitory potential. The chloroform fraction was the most potent fraction against AChE and BChE. The phenolic and flavonoids contents were also determined. In the crude extract and sub fractions chlorogenic acid, quercetin, phloroglucinol, rutin, Mandelic acidand hydroxy benzoic acid were identified through reverse phase HPLC. The ethyl acetate fraction was found to be rich in phenolic active compounds and was therefore subjected to column isolation. Two compounds, quercetin and mandelic acid were isolated in the pure state. The isolation and purity of isolated compounds were evident from broad single peak in the HPLC chromatogram. The isolated compounds were then confirmed through FTIR and ${ }^{1}$ HNMR. From the results it was concluded that the fruit of this plant is a good radical scavenger which could be used to minimize oxidative stress caused by reactive oxygen species.
Studies are needed in the same lines to evaluate other potentials of this plant as well.

\section{Methods}

\section{Plant sample collection}

The fruits of the Aesculus indica were collected from Laram Mountain village Ouch, Dir Lower KPK Pakistan in January 2015 and were authenticated by the Botanist in the department of Botany University of Malakand. A voucher specimen $(1020 \mathrm{HU})$ was also deposited in the Herbarium of Malakand University.

\section{Chemicals, drugs and standards}

Quercetin, morin, rutin, pyrogallol, mandelic acid, hydroxy benzoic acid, phloroglucinol and chlorogenic acid, Follin-ciocalteu reagent, sodium carbonate, 2,2-diphenyle-1 picrylhydrazyle [DPPH], aluminum chloride, sodium nitrate, sodium hydroxide, ethanol, methanol, ascorbic acid, distilled water, 5,5-dithio-bis-nitrobenzoic acid (DTNB), 2,2'-azino-bis-3 ethylbenzothiazoline-6sulfonic acid (ABTS) were all purchased from Sigma Aldrich. Butyrylthiocholine iodide, acetylthiocholine iodide, acetyl cholinesterase from Electric eel (type-VI-S) and butyrylcholinesterase from Equine were obtained from Sigma-Aldrich USA and were used in enzyme inhibition assays. All solvents used in the assays were of HPLC grades purchased from Dae-Jung Korea.

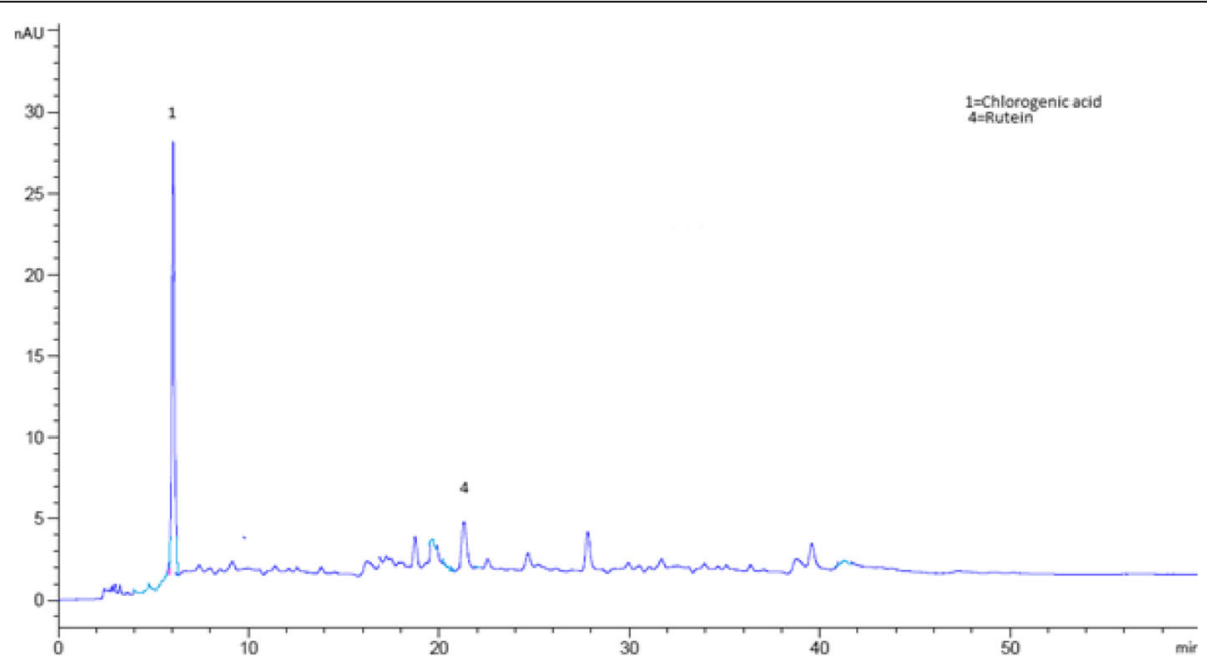

Fig. 5 HPLC Chromatogram of Chloroform Fraction 
Table 6 Concentration of antioxidants in chloroform fraction

\begin{tabular}{llllll}
\hline S. No & Peak & Retention time $(\mathrm{min})$ & Possible identity & Quantity $(\mathrm{mg} / 100 \mathrm{~g})$ & Identification reference \\
\hline 1 & 1 & 6.005 & Chlorogenic acid & 1.520 & Standard \\
2 & 4 & 22.623 & Rutin & 3.67 & Standard
\end{tabular}

\section{Extraction and fractionation}

Fresh fruits of the Aesculus indica were thoroughly washed with tape water to remove dust and soil contaminants. After this for drying it was kept at room temperature in a shady place for 4 weeks. The dried plant sample was grinded into fine powder. To prepare crude extract, the powder sample was soaked in $90 \%$ methanol for $72 \mathrm{~h}$. Then the mixture was subjected to filtration through whattman filter paper and the residue left was again dipped in methanol for additional $72 \mathrm{~h}$ and the mixture was filtered again. The filtrates obtained from above two steps were then combined. The filtrates were then concentrated at $40{ }^{\circ} \mathrm{C}$ in rotary evaporator (Rota vapor R-200 Buchi, Switzerland) and the extract was obtained in semisolid form. It was then kept in open atmosphere to evaporate the remaining solvent and was converted into solid form. The crude extract was subjected to fractionation. In brief $300 \mathrm{~g}$ crude extract was suspended in $900 \mathrm{ml}$ of methanol and subjected to solvent-solvent extraction for fractionation. All these fractions were separated in separating funnels and stored into flasks and labeled with different code and kept in a refrigerator at a temperature of $4{ }^{\circ} \mathrm{C}$. All fractions collected were then subjected to isolation of antioxidants and biological activities.

\section{Determination of free radical scavenging activity using DPPH assay}

The free radical scavenging ability of the extracts were determined by using 2, 2- Diphenyl-1-picrylhydrazyl
(DPPH) assay modified by Brand-Williams [17]. DPPH solution was prepared by dissolving $20 \mathrm{mg}$ in $100 \mathrm{ml}$ of methanol (stock solution) and then from this solution $3 \mathrm{ml}$ were taken and its absorbance at $515 \mathrm{~nm}$ was adjusted to 0.70 . This was considered as control solution. This stock solution was then covered with aluminum foil and kept in dark place for $24 \mathrm{~h}$ for the formation of free radical. After this $5 \mathrm{mg}$ was taken from each extracts and were dissolved in $5 \mathrm{ml}$ of methanol (stock solutions). From each stock solution different diluted solutions such as 1000, 500, 250, 125, $62.5 \mu \mathrm{g} / \mathrm{ml}$ were prepared through serial dilution. From these diluted solutions, $2 \mathrm{ml}$ were mixed with $2 \mathrm{ml} \mathrm{DPPH}$ and were allowed to react in darkness for $15 \mathrm{~min}$. The following equation was used to calculate the percent inhibition of DPPH by extracts:

$$
\text { \%inhibition }=\frac{A-B}{A} \times 100
$$

Where; $\mathrm{A}=$ absorbance of pure $\mathrm{DPPH}$ in oxidized form.

$\mathrm{B}=$ absorbance of sample taken after $15 \mathrm{~min}$ of reaction with DPPH.

For the determination of $\mathrm{IC}_{50}$ values of the extracts the same concentrations solutions of ascorbic acid were prepared (1000, 500, 250, 125, $62.5 \mu \mathrm{g} / \mathrm{ml})$ and same procedure was used to determined its percent DPPH free radical inhibition. The $\mathrm{IC}_{50}$ is the concentration at which $50 \%$ of DPPH solution is scavenged.

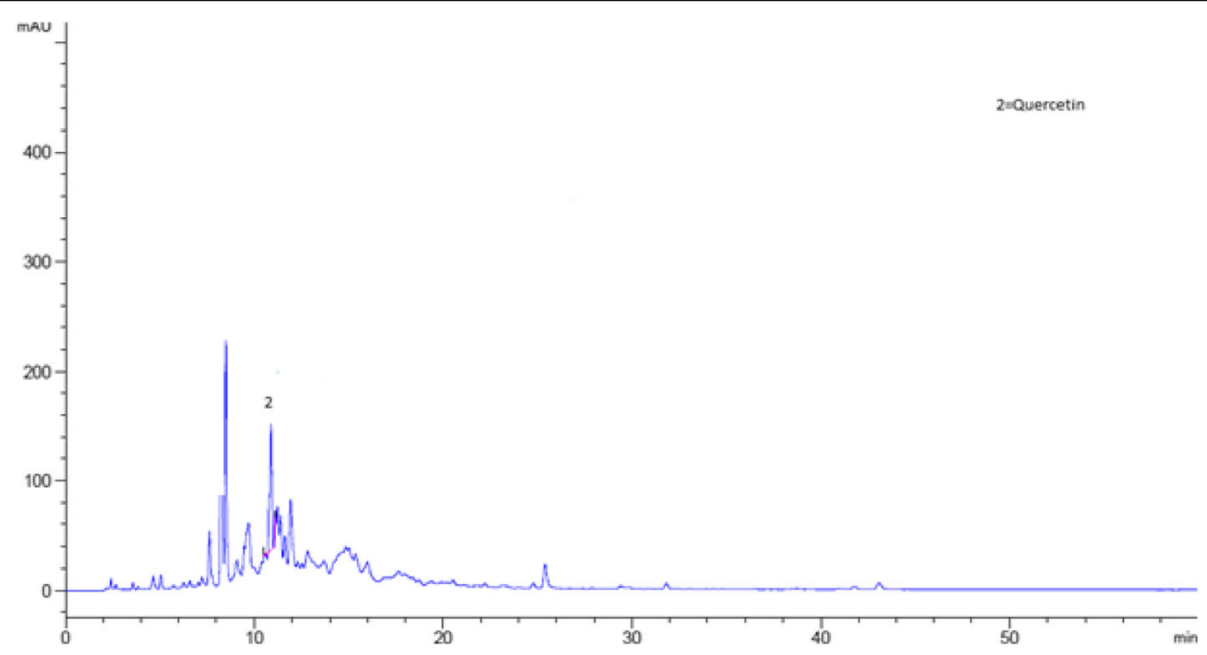

Fig. 6 HPLC Chromatogram of n-hexane Fraction 
Table 7 Concentration of antioxidants in n-hexane fraction

\begin{tabular}{|c|c|c|c|c|c|}
\hline S. No & Peak & Retention time (min) & Possible identity & Quantity (mg/100 g) & Identification reference \\
\hline 1 & 2 & 10.062 & Quercetin & 0.0406 & Standard \\
\hline
\end{tabular}

\section{Free radical scavenging activity by ABTS assay}

The ABTS free radicals scavenging by crude extract and sub-fractions were determined following standard procedure of Re et al. [18]. For the preparation of ABTS free radical solution, $7 \mathrm{mM}$ of ABTS and potassium per sulphate $(2.45 \mathrm{mM})$ were dissolved separately in $100 \mathrm{ml}$ of methanol and thoroughly mixed. To produce ABTS free radical, the mixture was kept in dark for one night. The absorbance of ABTS free radical was adjusted to 0.7 at $745 \mathrm{~nm}$ by dilution with $50 \%$ methanol. Three-hundred microliter of test samples (extracts) were mixed $3 \mathrm{ml}$ of ABTS solution and were kept for $15 \mathrm{~min}$ in incubator at $25{ }^{\circ} \mathrm{C}$. After incubation the absorbance of the mixture was measured at $745 \mathrm{~nm}$ using a double beam spectrophotometer. The same procedure was followed for the preparation of different dilution of ascorbic acid which was used as positive control. The percent ABTS free radical inhibition was calculated by formula:

$$
\text { Percent scavenging activity }=\frac{A-B}{A} \times 100
$$

Where A is the absorbance of ABTS and B is the absorbance of sample.

\section{Anticholinesterase assays}

Acetyl cholinesterase (AChE) and butyrylcholineaterase (BChE) were used to examine the enzyme inhibitory potential of crude extract and sub-fractions using Ell men's assay [19] which is based on the hydrolysis of Acetylthiocholine iodide or butyrylthiocholine iodide by respective enzyme and the formation of 5-thio-2- nitrobenzoate anion followed by DTNB complexation to give yellow color compound which is detected after reaction time of $15 \mathrm{~min}$ by spectrophotometer.

\section{Preparation of required solutions}

Phosphate buffer was prepared by dissolving $13.6 \mathrm{~g} / \mathrm{L}$ of $\mathrm{KH}_{2} \mathrm{PO}_{4}$ and $17.4 \mathrm{~g} / \mathrm{L}$ of $\mathrm{K}_{2} \mathrm{HPO}_{4}$, separately in $100 \mathrm{ml}$ of distilled water. The phosphate buffer of $\mathrm{pH} 8$ was prepared by mixing $6 \%$ of $\mathrm{KH}_{2} \mathrm{PO}_{4}$ with $94 \%$ of $\mathrm{K}_{2} \mathrm{HPO}_{4}$. The AChE and BChE were diluted in freshly prepared buffer of $\mathrm{pH} 8.0$ to achieve a final concentration of 0.03 and $0.01 \mathrm{U} / \mathrm{mL}$ respectively. To prepare DTNB solution $(0.0002 \mathrm{M})$ in $10 \mathrm{ml}$ of phosphate buffer and shake well and then the final volume was made up to $100 \mathrm{ml}$. The AChEI and BChEI solutions $(0.0005 \mathrm{M})$ were also prepared in phosphate buffer separately in $100 \mathrm{ml}$.

\section{Spectroscopic analysis}

For spectroscopic determination of the enzyme inhibition, $1 \mathrm{ml}$ of crude extract and sub fractions (125$1000 \mu \mathrm{g} / \mathrm{ml}$ ) were taken separately in a series of test tubes. Then to these solutions $100 \mu \mathrm{l}$ of enzyme and DTNB solutions were added and kept in incubator for $15 \mathrm{~min}$ at $25^{\circ} \mathrm{C}$. After this $100 \mu \mathrm{l}$ substrates (AChEI, $\mathrm{BChEI}$ ) were added to each test tube and allowed to stand for $15 \mathrm{~min}$ to proceed the reaction. Then the absorbance was measured at $412 \mathrm{~nm}$. For negative control solution all the above mentioned components except plant extracts were mixed in the mentioned order. Galanthamine was used as a positive control. The same procedure mentioned above was used for reaction mixture of positive control and absorbance was measured at $412 \mathrm{~nm}$. For each sample absorption was recorded for

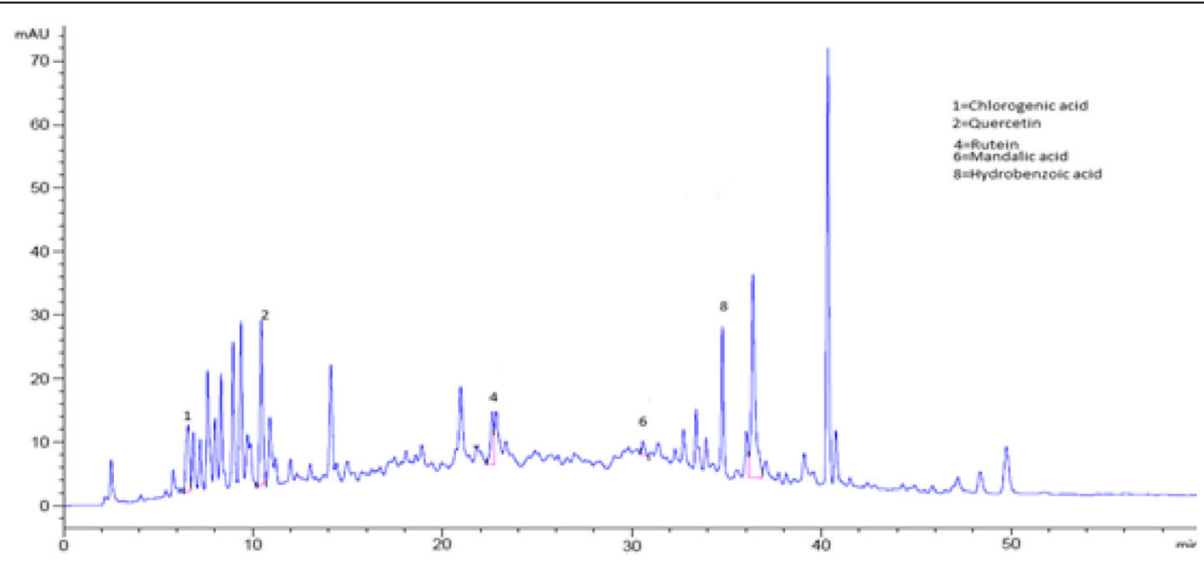

Fig. 7 HPLC Chromatogram of Aqueous Fraction 
Table 8 Concentration of antioxidants in aqueous fraction

\begin{tabular}{llllll}
\hline S. No & Peak & Retention time $(\mathrm{min})$ & Possible identity & Quantity $(\mathrm{mg} / 100 \mathrm{~g})$ & Identification reference \\
\hline 1 & 1 & 6.005 & Chlorogenic acid & 1.617 & Standard \\
2 & 2 & 10.062 & Quercetin & 3.92 & Standard \\
3 & 4 & 22.623 & Rutin & 0.014 & Standard \\
4 & 6 & 30.597 & Mandelic acid & 2.68 & Standard \\
5 & 8 & 36.211 & Hydroxy benzoic acid & 3.19 & Standard \\
\hline
\end{tabular}

4 min. Percent activity of enzyme and percent inhibition were calculated using following relation:

$$
\begin{aligned}
& V=\frac{\Delta A b s}{\Delta T} \\
& \text { \%enzyme activity }=\frac{V}{V \max } \times 100 \\
& \text { \%enzyme inhibition }=100-\% \text { enzyme activity }
\end{aligned}
$$

Where $\mathrm{V}$ represents the rate of reaction in the presence of inhibitor and $V_{\max }$ is the rate of reaction without inhibitor.

\section{Determination of total phenolic content}

The total phenolic contents were estimated using Follin-ciocalteu assay [20]. For the preparation of required solution of these extracts (crude and sub fractions) $5 \mathrm{mg}$ of each samples were dissolved in $5 \mathrm{ml}$ of methanol. After this $1 \mathrm{ml}$ of Follin-ciocalteu reagent was taken and added into $10 \mathrm{ml}$ of distilled water to prepared diluted solution of Follin-ciocalteu reagent. For the preparation of reaction mixtures $1 \mathrm{ml}$ of extracts solutions were taken in a test tube and $9 \mathrm{ml}$ of distilled water were added to each. Then $1 \mathrm{ml}$ of diluted solution of Follin-ciocalteu reagent was also added to each test tube and allowed to stand for $6 \mathrm{~min}$. After $6 \mathrm{~min} 10 \mathrm{ml}$<smiles>O=c1c(O)c(-c2ccc(O)c(O)c2)oc2cc(O)cc(O)c12</smiles>

C

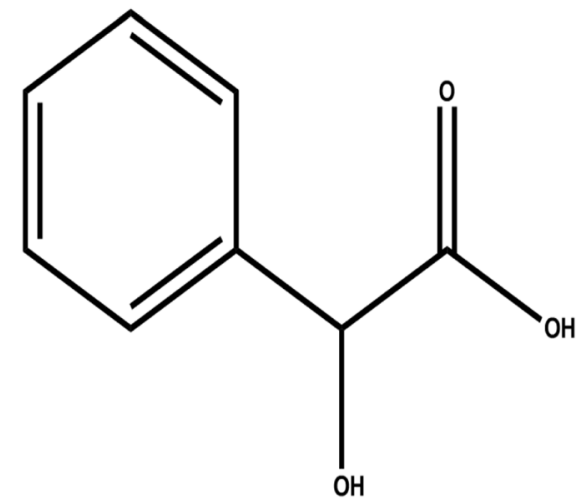

b

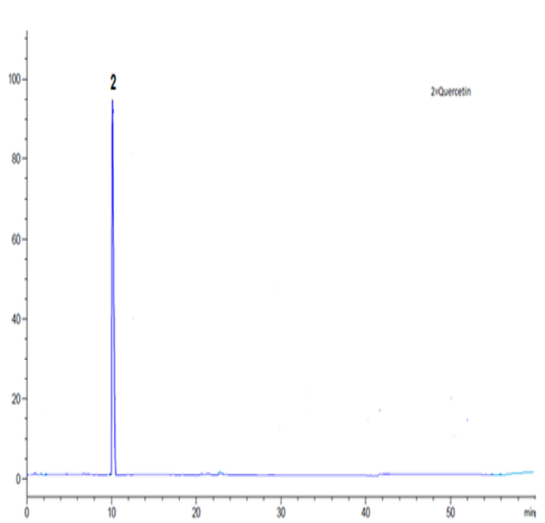

d

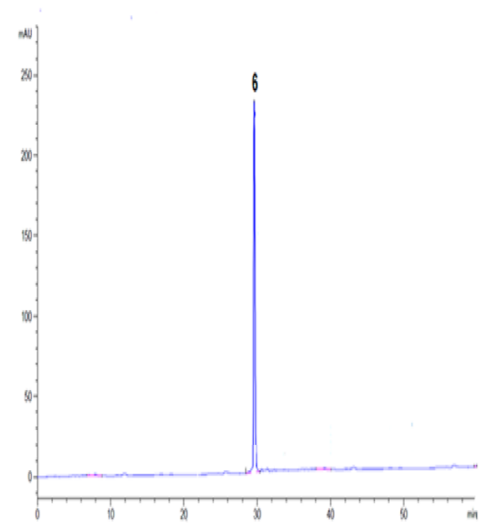

Fig. 8 Structural formulae and HPLC chromatograms of isolated compounds ( $\mathbf{a}=$ quercetin, $\mathbf{b}=$ HPLC chromatogram of quercetin, $\mathbf{c}=$ structure of mandelic acid $\mathbf{d}=$ HPLC chromatogram of mandelic acid) 
Table 9 Percent ABTS and DPPH Radical Scavenging Potential of quercetin and Mandelic acidisolated from Aesculus Indica Fruit

\begin{tabular}{|c|c|c|c|c|c|}
\hline Samples & $\begin{array}{l}\text { Concentrations } \\
(\mu \mathrm{g} / \mathrm{mL})\end{array}$ & $\begin{array}{l}\text { DPPHpercent inhibition } \\
(\text { mean } \pm \text { S.E.M) }\end{array}$ & $\begin{array}{l}\mathrm{DPPHIC}_{50} \\
(\mu \mathrm{g} / \mathrm{mL})\end{array}$ & $\begin{array}{l}\text { ABTS percent inhibition } \\
\text { (mean } \pm \text { S.E.M) }\end{array}$ & $\begin{array}{l}\text { ABTSIC }_{50} \\
(\mu \mathrm{g} / \mathrm{mL})\end{array}$ \\
\hline \multirow[t]{5}{*}{ Quercetin } & 1000 & $81.91 \pm 0.70^{* * *}$ & & $79.80 \pm 2.51^{* *}$ & \\
\hline & 500 & $70.75 \pm 1.72^{* * *}$ & & $66.08 \pm 0.40^{* * *}$ & \\
\hline & 250 & $58.25 \pm 1.30^{* * *}$ & 78 & $55.01 \pm 1.60^{* * *}$ & 180 \\
\hline & 125 & $48.44 \pm 0.62^{* * *}$ & & $43.30 \pm 3.13^{* * *}$ & \\
\hline & 62.5 & $35.67 \pm 0.59^{* * *}$ & & $32.46 \pm 0.50^{* * *}$ & \\
\hline \multirow[t]{5}{*}{ Mandelic acid } & 1000 & $78.54 \pm 2.00^{* * *}$ & & $72.70 \pm 1.54^{* * *}$ & \\
\hline & 500 & $67.16 \pm 0.56^{* * *}$ & & $62.60 \pm 1.72^{* * *}$ & \\
\hline & 250 & $57.71 \pm 0.52^{* * * *}$ & 120 & $50.66 \pm 2.20^{* * *}$ & 240 \\
\hline & 125 & $45.50 \pm 2.56^{* * *}$ & & $39.84 \pm 0.99^{* * *}$ & \\
\hline & 62.5 & $30.57 \pm 1.23^{* * *}$ & & $27.15 \pm 0.76^{* * *}$ & \\
\hline \multirow[t]{5}{*}{ Ascorbic acid } & 1000 & $94.35 \pm 0.73$ & & $89.94 \pm 0.86$ & \\
\hline & 500 & $85.92 \pm 0.96$ & & $80.29 \pm 0.79$ & \\
\hline & 250 & $80.74 \pm 1.19$ & 38 & $70.22 \pm 2.23$ & 58 \\
\hline & 125 & $67.61 \pm 0.80$ & & $62.97 \pm 2.26$ & \\
\hline & 62.5 & $56.31 \pm 0.76$ & & $50.88 \pm 0.30$ & \\
\hline
\end{tabular}

Ascorbic acid was used as a positive control. Data is represented as mean \pm S.E.M; $(n=3)$. Values significantly different as compared to positive control, ${ }^{* *} P<0.01$; *** $P<0.001$

of $7 \%$ of sodium carbonate and $10 \mathrm{ml}$ of distilled water was added to the reaction mixture. Then the mixture was diluted further to $25 \mathrm{ml}$ with the addition of distilled water and were shaken thoroughly. The absorbance of each solution was recorded after $90 \mathrm{~min}$ at $760 \mathrm{~nm}$ through UV spectrophotometer. For the determination of total phenolic content standard gallic acid curve ( 0 to $100 \mathrm{mg} / \mathrm{ml}$ ) was drawn. The total phenolic contents were expressed as milligrams of Gallic acid equivalent (mg GAE/g per gram of dry sample).

\section{Determination of total flavonoid content}

For the determination of total flavonoid contents, the procedure of Park et al. was followed [21]. About $5 \mathrm{mg}$ of each of these extracts (crude and sub fractions) were dissolved in $5 \mathrm{ml}$ of methanol. From which $1 \mathrm{ml}$ was taken from each and mixed with $9 \mathrm{ml}$ of distilled water. Then to the mixture $1 \mathrm{ml}$ of $5 \%$ sodium nitrate $\left(\mathrm{NaNO}_{2}\right)$ was added and allowed to stand for $6 \mathrm{~min}$. Then $2 \mathrm{ml}$ of $10 \%$ aluminum chloride solution was added to it and allowed to stand for $5 \mathrm{~min}$. After this $2 \mathrm{ml}$ solution of $1 \mathrm{M}$ sodium hydroxide was added sequentially to each tube. The absorbance of this reaction mixture was recorded at $510 \mathrm{~nm}$ through UV spectrophotometer. For the determination of total flavonoids standard quercetin solution curve (0 to $200 \mathrm{mg} / \mathrm{ml}$ ) was constructed. The total flavonoid contents were expressed in term of Quercetin equivalent (mg.QE/g of dry sample).

\section{Determination of phenolic contents through HPLC}

The HPLC system used was an Agilent 1260 infinity High-performance Liquid chromatography (HPLC) system having basic parts like quaternary pump, auto sampler, degasser and ultra violet (UV) detector. The separation was achieved via Agilent Zorbax Eclipse C18 column. The gradient system comprises of solvent A (methanol; acetic acid: deionized water, 10:2:88, $v / \mathrm{v}$ and solvent B (methanol: acetic acid deionized water, 90: 2: $8, v / v)$. the efficient gradient program was started with $100 \% \mathrm{~A}$ at $0 \mathrm{~min}, 85 \% \mathrm{~A}$ at $5 \mathrm{~min}, 50 \% \mathrm{~A}$ at $20 \mathrm{~min}, 30 \%$ $\mathrm{A}$ at $25 \mathrm{~min}$, and $100 \% \mathrm{~B}$ from 30 to $40 \mathrm{~min}$. The flow rate of sample was $1 \mathrm{ml} / \mathrm{min}$. The identification was performed by using retention times, available standards and UV spectra. Quantification of the identified compounds was on the basis of \% peaks.

For the preparation of samples for HPLC analysis, $1 \mathrm{~g}$ of the powder sample (in case of fractions solid extract) was dissolved in $10 \mathrm{~mL}$ methanol/water $(5,5)$ mixture, overtaxing for $15 \mathrm{~min}$ and then shaking for $1 \mathrm{~h}$. After this the mixtures were filter with Whattman filter paper having pore size of $0.7 \mu \mathrm{m}$. Then filtered samples were centrifuged at $4000 \mathrm{rpm}$ for $15 \mathrm{~min}$. After centrifugation the solvent was evaporated under vacuum at $35^{\circ} \mathrm{C}$ up to $2 \mathrm{ml}$ volume. It was filtered again through PTFE Agilent with pore size of $0.45 \mu \mathrm{m}$. The filtrate were collected into $2 \mathrm{ml} \mathrm{HPLC}$ vials and were labeled with proper code and placed in a refrigerator. Standard solutions of quercetin, morin, rutin, mandelic acid, pyrogallol, hydroxy benzoic acid, phloroglucinol and chlorogenic acid were 
prepared in methanol. A standard chromatogram was developed for the mixture of HPLC standards mentioned above. HPLC chromatogram of Aesculus indica fruit crude extract and chloroform, ethyl acetate, n-hexane and aqueous sub fractions were also obtained.

By comparing these chromatograms with the standard one, the phenolic compounds identified in the crude extract were; quercetin, phloroglucinol, mandelic acid and hydroxy benzoic acid. In the ethyl acetate fraction the phenolic compounds identified were; quercetin, mandelic acid and hydroxy benzoic acid. In the other fraction (n-hexane, chloroform, and aqueous) the amount of phenolic compound present were very small as compared to crude extract and ethyl acetate fraction.

\section{Isolation of phenolic compounds}

The HPLC chromatograms obtained for the fractions showed that ethyl acetate fraction contains greater number of phenolic compounds and was therefore subjected to silica gel column for the isolation of bioactive compounds.

Column chromatography is generally used to isolate and purify the components of complex mixtures. Silica gel column chromatography was used for separation and isolation of pure compounds from ethyl acetate fraction. For the preparation of column, silica gel was suspended in required solvent and left for $4 \mathrm{~h}$ to soak and was then poured into the column. The solid ethyl acetate extract fraction was dissolved in the minimum amount of particular solvent in which it was soluble and filtered to remove impurities, which could otherwise will cause diffusion problems while packing the column. After this, the slurry of the fractions with silica gel were developed which was then loaded over silica gel column using a pipette with the help glass rods with great care in such a way to not disturb the top of the column. After loading the sample to column it was eluted with ethyl acetate and n-hexane mixtures $\{1: 4(20 \%), 1: 3(25 \%), 3: 7(30 \%)$, 7:13 (35\%), 2:3 (40\%), 9:11 (45\%), 1:1 50\%)\} with the help of peristaltic pump (SEKO, Italy). The vials collected were spotted on TLC and visualized in the UV light.

The 12 sub fractions were obtained and were again subjected to column chromatography (pencil column). Two compounds quercetin and mandelic acid were isolated in pure form. The purity and isolation of the compounds were confirmed through HPLC where a single broad peak was observed. The structure of these compounds was elucidated by spectrophotometric techniques like FT-IR and $\mathrm{H}^{1} \mathrm{NMR}$.

\section{Estimation of $\mathrm{IC}_{50}$ values}

Concentrations of the plant extract at which $50 \%$ of inhibition was observed $\left(\mathrm{IC}_{50}\right)$, were calculated amongst the inhibition percentages against the extract concentrations via the Excel program.

\section{Statistical data analysis}

All the assays were repeated in triplicate and values have been expressed as means \pm standard error means (SEM). Statistical analyses were performed by Two-way analysis of variance (ANOVA), followed by Bonferroni post-tests. The difference was considered to be statistically significant when the $p$ value was less than 0.05 .

\section{Determination of $\mathrm{R}^{2}$ and $\mathrm{Y}$}

Regression (y) and linear correlation $\left(\mathrm{R}^{2}\right)$ for phenolic and flavonoid contents vs various activities (anticholinesterase and antioxidants) were determined using Microsoft Excel 2007.

\section{Additional file}

\begin{abstract}
Additional file 1: Figure S1. \% DPPH free radical scavenging effect of Aesculus indica crude extract and their sub fraction along with ascorbic acid taken as a standard. Figure S2. Percent ABTS scavenging effect of Aesculus indica of crude extract and their sub fraction along with ascorbic acid at various concentrations. Figure S3. \% AChE inhibition potential of Aesculus indica fruit crude extract and their different sub fraction. Figure S4. \% BChE inhibition potential of Aesculus indica fruit crude extract and their different sub fraction. Figure S5. Total phenolic content in Aesculus indica fruit crude extract and different sub fraction. Figure S6. Total Flavonoid content in Aesculus indica fruit crude extract and different sub fraction. Figure S7. FTIR Spectra of the isolated compound Quercetin. Figure S8. NMR Spectra of Quercetin. Figure S9. FT-IR spectra of the isolated compound Mandalic acid. Figure S10. NMR Spectra of Mandalic acid. Figure S11. \% DPPH free radical scavenging effect of quercetin and mandalic acid isolated from Aesculus indica fruit using ascorbic acid taken as a standard. Figure S12. \% ABTS free radical scavenging effect of quercetin and mandalic acid isolated from Aesculus indica fruit using ascorbic acid taken as a standard. (DOCX $645 \mathrm{~kb}$ )
\end{abstract}

\section{Acknowledgments \\ The authors are grateful to Higher Education commission of Pakistan for their financial support (Project No: 20-2515/R\&D/HEC).}

Availability of data and materials

The data in form of thesis will be provided on demand.

\section{Authors' contributions}

SS and HU carried out the experimental work, AS and FU helped in enzyme inhibitory activities while MZ conceived the idea, supervised the work and wrote the research paper. All authors read and approved the final manuscript.

Ethics approval and consent to participate Not applicable

Consent for publication

All the authors have read and given the consent for publication.

Competing interests

The authors declare that they have no competing interests.

\section{Publisher's Note}

Springer Nature remains neutral with regard to jurisdictional claims in published maps and institutional affiliations. 
Received: 4 October 2017 Accepted: 17 June 2018

Published online: 26 June 2018

\section{References}

1. Ali M, Arfan M, Zaman M, Ahmad K, Akbar H, Anis N, Shah I, Raza M. Ant proliferative activity and chemical constituents of Hypericumoblongi folium. J Chem Soc Pakistan. 2011;33:772-7.

2. Song JY, Kwon EY, Kim BS. Biological synthesis of platinum nanoparticles using Diopyros kaki leaf extract. Bioprocess Biosyst Eng. 2010;33(1):159-64.

3. Ayaz M, Junaid M, Ahmed J, Ullah F, Sadiq A, Ahmad S, Imran M. Phenolic contents, antioxidant and anticholinesterase potentials of crude extract, subsequent fractions and crude saponins from Polygonumhydropiper. L. BMC Complement Altern Med. 2014;14:145-53.

4. Ahmed M, Phul A, Haq I, Bibi G, Mazhar K, Rehman T, Zia M, Mirza B. Antioxidant, anticancer and antibacterial potential of Zakhm-e-hayat rhizomes crude extract and fractions. Pak J Pharm Sci. 2016;29:895-902.

5. Tomczyka M, Latteb KP. A review of phytochemical and pharmacological profile of potentials species. J Eth Pharm. 2009;122:184-204.

6. Reid k A, Jäger AK, Light ME, Mulholland DA, Van Staden J. Phytochemical and pharmacological screening of Sterculiaceae species and isolation of antibacterial compounds. J Ethnopharmacol. 2005;97:285-91.

7. Basma AA, Zakaria Z, Latha LY, Sasidharan S. Antioxidant activity and phytochemical screening of the methanol extracts of Euphorbia hirta $\mathrm{L}$. Asian Pac J Trop Med. 2011;4:386-90.

8. Khasawneh M, Elwy HM, Fawzi NM, Hamza AA, Chevidenkandy AR, Hassan $\mathrm{AH}$. Antioxidant activity and lipoxygenase inhibitory effect of Carallumaarabica and related polyphenolic constituents. Amer J Plant. 2014; 5:1623-163.

9. Hamid A, Aiyelaagbe OO, Usman L, Ameen MO, Lawal A. Antioxidants its medicinal and pharmacological applications. Afr J Pure Appl Chem. 2010;4: 142-51.

10. Suryanti $V$, Marliyana SD, Putri HE. Effect of germination on antioxidant activity, total phenolics, $\beta$-carotene, ascorbic acid and a-tocopherol contents of lead tree sprouts (Leucaenaleucocephala (Imk.) de Wit). Int Food Res J. 2016;23:167-72.

11. Pettitt $P$. The Neanderthal dead: exploring mortuary variability in middle Palaeolithic Eurasia. Before Farming. 2001;1(4):1-19.

12. Reddy CVK, Sreeramulu D, Raghunath M. Antioxidant activity of fresh and dry fruits commonly consumed in India. Food Res Int. 2010;43:285-8.

13. Kumar $\mathrm{S}$. The importance of antioxidant and their role in pharmaceutical science. Asian J Res Chem Pharm Sci. 2014;1(1):27-44.

14. Chakraborthy GS. Antioxidant activity of the successive extracts of Aesculus indica leaves. Int J Pharm Sci Drug Res. 2009;2:121-3.

15. Albayrak S, Aksoy A, Sagdic O, Hamzaoglu E. Compositions, antioxidant and antimicrobial activities of Helichrysum (Asteraceae) species collected from Turkey. Food Chem. 2010;119:114-22.

16. Selvaraj K, Chowdhury R, Bhattacharjee C. Isolation and structural elucidation of flavonoids from aquatic fern azolla microphylla and evaluation of free radical scavenging activity. Int J Pharm Sci. 2013;5:743-9.

17. Brand W, Williams M, Cuvelier C. Use of a free radical method to evaluate antioxidant activity. Food Sci Technol. 1995;28:25-30.

18. Re R, Pellegrini N, Proteggente A, Pannala A, Yang M, Rice C. Antioxidant activity applying an improved ABTS radical cation decolorization assay. Free Radic Biol Med. 1999;26:1231-7.

19. Sadiq A, Ahmad S. Phenolic contents, antioxidant and anticholinesterase potentials of crude extract, subsequent fractions and crude saponins from Polygonum hydro piper L. BMC Complement Altern Med. 2014;14:145.

20. Meda A, Lamien CE, Romito M, Millogo J, Nacoulma OG. Determination of the total phenolic, flavonoid and proline contents in Burkina Fasan honey, as well as their radical scavenging activity. Food Chem. 2005;91:571-7.

21. Park HH, Lee S, Son HY, Park SB, Kim MS, Choi EJ, Singh TS, Ha JH, Lee MG, Kim JE, Hyun MC, Kwon TK, Kim YH, Kim SH. Flavonoids inhibit histamine release and expressing on of proinflammatory cytokines in mast cells. Arch Pharm Res. 2008;31:1303-11.

\section{Ready to submit your research? Choose BMC and benefit from:}

- fast, convenient online submission

- thorough peer review by experienced researchers in your field

- rapid publication on acceptance

- support for research data, including large and complex data types

- gold Open Access which fosters wider collaboration and increased citations

- maximum visibility for your research: over $100 \mathrm{M}$ website views per year

At BMC, research is always in progress.

Learn more biomedcentral.com/submissions 